\title{
Synergic effect between 5-fluorouracil and celecoxib on hypoxic gastric cancer cells
}

\author{
XIAO-QIAN ZHANG ${ }^{1,2}$, XIU-E SUN ${ }^{2}$, WEN-DONG LIU ${ }^{3}$, YU-GUANG FENG ${ }^{2}$, HONG-MEI ZHANG ${ }^{2}$, \\ LI-HONG SHI ${ }^{4}$, XIU-NING SUN ${ }^{5}$, YAN-QING LI ${ }^{1}$ and ZHI-XING GAO ${ }^{2}$ \\ ${ }^{1}$ Department of Gastroenterology, Qilu Hospital, Shandong University, Jinan, Shandong 250012; \\ ${ }^{2}$ Department of Gastroenterology; ${ }^{3}$ Blood Bank, Affiliated Hospital of Weifang Medical University, \\ Weifang, Shandong 261031; Departments of ${ }^{4}$ Pharmacology and ${ }^{5}$ Parasitology, \\ Weifang Medical University, Weifang, Shandong 261053, P.R. China
}

Received March 9, 2013; Accepted August 14, 2014

DOI: $10.3892 / \mathrm{mmr} .2014 .2783$

\begin{abstract}
FU) is commonly used in the treatment of gastric cancer; however, resistance to this drug occurs under hypoxic conditions. Celecoxib may be used to reverse this resistance. The aim of the present study was to elucidate the inhibitory effects and mechanisms of 5-FU and celecoxib on the gastric cancer cell line SGC7901 under hypoxic conditions. SGC7901 cells were divided into four groups: Hypoxic control group, 5-FU group, celecoxib group and 5-FU/celecoxib combination group. Following treatment, the inhibition rates of cells were determined using an MTT assay. Protein and messenger RNA (mRNA) expression of hypoxia-inducible factor $2 \alpha$ (HIF-2 $\alpha$ ), adenosine triphosphate-binding cassette sub-family $\mathrm{G}$ member 2 (ABCG2) and octamer binding protein 4 (Oct-4) were determined using immunohistochemistry, reverse transcription quantitative polymerase chain reaction (RT-qPCR) and western blot analysis. The results demonstrated that the 5-FU/celecoxib combination group had a significantly higher inhibition rate than the individually treated 5-FU and celecoxib groups $(\mathrm{P}<0.05)$; inhibition rates were $66.09,52.61$ and $46.1 \%$, respectively. mRNA and protein expression levels of HIF-2 $\alpha$, ABCG2 and Oct-4 were significantly lower in the celecoxib and 5-FU/celecoxib combination groups $(\mathrm{P}<0.01)$ compared with those of the hypoxia control and 5-FU groups. The 5-FU group demonstrated the highest
\end{abstract}

Correspondence to: Dr Yan-Qing Li, Department of Gastroenterology, Qilu Hospital, Shandong University, 107 Wenhua Xi Road, Jinan, Shandong 250012, P.R. China

E-mail: liyanq55@163.com

Dr Zhi-Xing Gao, Department of Gastroenterology, Affiliated Hospital of Weifang Medical University, 2428 Yuhe Road, Weifang, Shandong 261031, P.R. China

E-mail: gaozhixing119@163.com

Key words: 5-fluorouracil, celecoxib, hypoxia-inducible factor $2 \alpha$, adenosine triphosphate-binding cassette sub-family $\mathrm{G}$ member 2 , octamer binding protien 4 , gastric cancer levels of the respective mRNA and proteins. In conclusion, the results of the present study indicated that celecoxib had anti-tumor effects, as it was shown to inhibit tumor cell growth via the inhibition of HIF-2 $\alpha$, ABCG2 and Oct- 4 . The 5-FU/celecoxib combination had a synergic effect on tumor growth inhibition. This therefore suggested that inhibition of HIF-2 $\alpha$, ABCG2 and Oct- 4 may be a potential method of reducing chemotherapy resistance and enhancing the effectiveness of chemotherapy treatment.

\section{Introduction}

Gastric cancer is a prevalent type of cancer with high mortality rates throughout the world, which is often diagnosed at an advanced stage $(1,2)$. The five-year survival rate was reported to be $70-75 \%$ for stage I disease, which drops to $35 \%$ for stage II (2). Numerous efforts have been taken to improve therapies and survival; at present, chemotherapy is one of the primary treatments for gastric cancer (3). However, chemotherapy treatment is not always effective; hypoxia, a characteristic of solid tumors, including gastric cancer, has been reported to induce chemotherapy resistance (4).

5-fluorouracil (5-FU) is an antimetabolite chemothrapeutic drug which targets thymidylate synthase, blocking the transformation of deoxy-uridine monophosphate into deoxy-thymidine acid. This results in cell death via decreased DNA synthesis and S-phase arrest (5). Clinical trials showed that regimens containing 5-FU improved the survival rate of gastric cancer patients; however, local treatment failure and distant metastases still occur $(3,6)$. Previous studies have demonstrated that hypoxic conditions induced cancer cell resistance to 5 -FU treatment in vitro $(7,8)$.

Celecoxib is a non-steroidal anti-inflammatory drug (NSAID) and a selective cyclooxygenase (COX)-2 inhibitor with anti-inflammatory and analgesic effects (9). Previous studies indicated that celecoxib may have a promising novel use in the treatment of cancer; however, its mechanism of action remains to be elucidated (10-12).

The aim of the present study was to assess the effects of celecoxib on hypoxic gastric cancer SGC7901 cells and determine whether celecoxib reduced the hypoxia-induced 
resistance of these cells to 5-FU. Furthermore, the present study aimed to elucidate the underlying mechanisms of action in order to improve the treatment of gastric cancer and increase the survival rate of patients.

\section{Materials and methods}

Materials. Human gastric cancer cells SGC7901 (Shandong Academy of Sciences, Jinan, China)and cobalt chloride $\left(\mathrm{CoCl}_{2}\right)$ were provided by Professor Feng from the Affiliated Hospital of Weifang Medical University (Weifang, China). The cells tested negative for mycoplasmic infection. 5-FU was obtained from Zhenguo Pharmaceutical Co., Ltd. (Jiangsu, China). RPMI 1640 medium was purchased from Gibco-BRL (Carlsbad, CA, USA). MTT kits were purchased from Sigma (St Louis, MO, USA). Fetal bovine serum (FBS) was obtained from Hyclone (Thermo Fisher Scientific, Waltham, MA, USA). Rabbit anti-hypoxia-inducible factor (HIF)-2 $\alpha$, anti-octamer binding protein (Oct)-4 and anti-adenosine triphosphate-binding cassette sub-family G member 2 (ABCG2) antibodies and immunohistochemical kits were for purchased from Abcam (Cambridge, MA, USA). TRIzol ${ }^{\circledR}$ reagent was purchased from Invitrogen Life Technologies (Carlsbad, CA, USA). Oligo-deoxy-thymine(dT), Moloney murine leukemia virus (M-MLV) reverse transcriptase, $5 \mathrm{X}$ reverse transcription buffer and $10 \mathrm{X}$ polymerase chain reaction (PCR) buffer were obtained from Fermentas (Waltham, MA, USA). A protein extraction kit was purchased from Biyuntian Biotech, Co. (Shanghai, China). Finally, the western blot enhanced chemiluminescence (ECL) reagent kit was obtained from Thermo Fisher Scientific (Waltham, MA, USA).

Cell culture. SGC7901 cells were inoculated in RPMI 1640 medium containing FBS (100 ml/1), penicillin and streptomycin $\left(10^{5} \mathrm{U} / \mathrm{l}\right)$. Cells were subcultured regularly at $37^{\circ} \mathrm{C}$ in a $5 \% \mathrm{CO}_{2}$ incubator. The chemical hypoxia-inducing agent $\mathrm{CoCl}_{2}(150 \mu \mathrm{mol} / \mathrm{l})$ was used to simulate the hypoxic microenvironment of solid tumors.

Proliferation inhibition rate. The proliferation inhibition rates of different concentrations of 5-FU and celecoxib in gastric cancer cells under hypoxia were determined by MTT assay. Cells in the logarithmic growth phase were inoculated in 96-well culture plates at a cell density of $2 \times 10^{4} / 1(200 \mu \mathrm{l})$. Cells were divided into four groups: The hypoxia control group, 5-FU group, celecoxib group and 5-FU/celecoxib combination group. $\mathrm{CoCl}_{2}$ was used to simulate a hypoxic microenvironment following the cells becoming adherent. The hypoxic control group was not treated with any drug. Cells in the 5-FU group were exposed to numerous concentrations of 5-FU $(25,50,100$ and $200 \mathrm{mg} / \mathrm{l})$. The celecoxib group was exposed to different concentrations of celecoxib $(50,100,200$ and $300 \mu \mathrm{mol} / \mathrm{l})$. Cells were cultured for 24, 48 or $72 \mathrm{~h}$ at $37^{\circ} \mathrm{C}$ in a $5 \% \mathrm{CO}_{2}$ incubator. Optical density (OD) for each well was measured using a microplate reader (Bio-rad 680; Bio-rad Laboratories, Inc., Hercules, CA, USA) at $490 \mathrm{~nm}$. Cell growth inhibition rates were calculated as: [(control OD-experimental OD)/control OD]x100\%. The half inhibitory concentrations $\left(\mathrm{IC}_{50}\right)$ of 5-FU and celecoxib under hypoxic conditions were calculated. The 5-FU/celecoxib combination group was subjected to 5-FU and celecoxib using their respective $\mathrm{IC}_{50}$. Cell growth inhibition rates were calculated following culturing the cells for 24,48 and $72 \mathrm{~h}$ at $37^{\circ} \mathrm{C}$ in a $5 \% \mathrm{CO}_{2}$ incubator.

Immunohistochemical detection of HIF-2 $\alpha, A B C G 2$ and Oct-4. SGC7901 cells in the logarithmic growth phase were prepared into a $4 \times 10^{4}$ cells $/ \mathrm{ml}$ suspension $(0.5 \mathrm{ml})$ and added to 24-well plates with cover glasses. Cells were separated into identical groups and subjected to identical conditions to those of the proliferation inhibition rate experiment. The cover glasses were removed following $48 \mathrm{~h}$ in culture. Cells were fixed using cold acetone for 10-15 min and then washed with PBS. Immunohistochemistry kits for HIF-2 $\alpha$, ABCG2 and Oct-4 were used according to the manufacturer's instructions. MDA-MB-231 breast cancer cells (Shanghai Baili Biological Technology Co., Shanghai, China) were used as the positive control and PBS in place of the primary antibodies was used as the negative control. Cytoplasms stained with yellowish brown pellets indicated a positive result.

HIF-2 $\alpha, A B C G 2$ and Oct -4 reverse transcription quantitative PCR (RT-qPCR). Cells were grouped and subjected to identical conditions as in the proliferation inhibition rate and immunohistochemistry experiments. TRIzol ${ }^{\circledR}$ was used to extract total RNA from the cells, RNA was then dissolved in $30 \mu 10.1 \%$ diethylpyrocarbonate water (Biyuntian Biotech,Co., Shanghai, China). Reverse transcription was performed in $20 \mu 1$ to obtain cDNA: RNAase-free deionized water $(9 \mu \mathrm{l})$, RNA template $(2 \mu \mathrm{l})$, Oligo-(dT)-18 $(1 \mu \mathrm{l})$, $5 \mathrm{X}$ reaction buffer $(4 \mu \mathrm{l})$, RNase inhibitor $(20 \mathrm{U} / \mu 1 ; 1 \mu \mathrm{l})$, dNTP mix (10 mmol/l; $2 \mu \mathrm{l})$, and M-MLV RT (1 $\mu \mathrm{l})$. Reaction conditions were: $70^{\circ} \mathrm{C}$ for $5 \mathrm{~min}$, then immediately put on ice for $5 \mathrm{~min} ; 25^{\circ} \mathrm{C}$ for $5 \mathrm{~min} ; 37^{\circ} \mathrm{C}$ for $60 \mathrm{~min}$; and $70^{\circ} \mathrm{C}$ for $10 \mathrm{~min}$. Samples were kept on ice if used immediately, or kept at $-150^{\circ} \mathrm{C}$ if used later.

Primer sequences for semi-quantitative PCR were: HIF- $2 \alpha$ forward, 5'-CTT GGA GGG TTT CAT TGC TGT GGT-3' and reverse, 5'-GTG AAG TCA AAG ATG CTG TGT CCT-3' (123 bp); ABCG2 forward, 5'-CCC TTA TGA TGG TGG CTT ATT C-3' and reverse, 5'-GTG AGA TTG ACC AAC AGA CCA T-3' (132 bp); Oct-4 forward, 5'-CCC GAA AGA GAA AGC GAA CC-3' and reverse, 5'-CAG AAC CAC ACT CGG ACC AC-3' (151 bp); and GAPDH forward, 5'-GCA CCA CCA ACT GCT TAG CAC-3' and reverse, 5'-GCA GCG CCA GTA GAG GCA GG-3' (1143 bp). PCR reaction (50 $\mu \mathrm{l})$ was performed using cDNA template $(1 \mu \mathrm{l})$, forward and reverse primers (1 $\mu \mathrm{l}$ each), Taq DNA polymerase $(1 \mu \mathrm{l})$, dioxynucleotide triphosphates $(2 \mathrm{mmol} / \mathrm{l}, 5 \mu \mathrm{l}), \mathrm{MgCl}_{2}(25 \mathrm{mmol} / \mathrm{l}, 2 \mu \mathrm{l})$, 10X PCR buffer $(5 \mu \mathrm{l})$ and double distilled $\mathrm{H}_{2} \mathrm{O}(34 \mu \mathrm{l})$. Conditions were as follows: $94^{\circ} \mathrm{C}$ for $5 \mathrm{~min}, 94^{\circ} \mathrm{C}$ for $30 \mathrm{sec}$, $50^{\circ} \mathrm{C}$ for $30 \mathrm{sec}$ and $72^{\circ} \mathrm{C}$ for $60 \mathrm{sec}$, for 40 cycles and then $72^{\circ} \mathrm{C}$ for $10 \mathrm{~min}$. Fragments were separated using $1.5 \%$ agarose gel electrophoresis. The MiniLumi digital photo gel imaging system (DNR Bio-Imaging Systems Ltd., Jerusalem, Israel) and Image J 1.26t (National Institutes of Health, Bethesda, MD, USA) were used to capture images of the gels. HIF-2 $\alpha$, ABCG2 and Oct-4 messenger RNA (mRNA) expression was determined based on the OD value using GAPDH as reference. 
Table I. Effect of treatment time and 5-FU concentration on proliferation of SGC7901 cells under hypoxic conditions.

\begin{tabular}{|c|c|c|c|c|c|c|}
\hline \multirow[b]{2}{*}{ Group } & \multicolumn{2}{|r|}{$24 \mathrm{~h}$} & \multicolumn{2}{|r|}{$48 \mathrm{~h}$} & \multicolumn{2}{|c|}{$72 \mathrm{~h}$} \\
\hline & OD & Inhibition rate $(\%)$ & OD & Inhibition rate $(\%)$ & OD & Inhibition rate $(\%)$ \\
\hline Hypoxia & $0.531 \pm 0.020$ & & $0.672 \pm 0.021$ & & $0.860 \pm 0.026$ & \\
\hline \multicolumn{7}{|l|}{$5-\mathrm{FU}$} \\
\hline $25 \mathrm{mmol} / \mathrm{l}$ & $0.416 \pm 0.017$ & 21.66 & $0.517 \pm 0.019$ & 23.07 & $0.652 \pm 0.025$ & 24.19 \\
\hline $50 \mathrm{mmol} / \mathrm{l}$ & $0.388 \pm 0.016$ & 26.93 & $0.468 \pm 0.022$ & 30.36 & $0.546 \pm 0.018$ & 36.51 \\
\hline $100 \mathrm{mmol} / \mathrm{l}$ & $0.349 \pm 0.015$ & 34.27 & $0.403 \pm 0.015$ & 40.03 & $0.459 \pm 0.016$ & 46.63 \\
\hline $200 \mathrm{mmol} / 1$ & $0.298 \pm 0.016$ & 43.88 & $0.334 \pm 0.010$ & 50.29 & $0.406 \pm 0.017$ & 52.80 \\
\hline
\end{tabular}

Mean \pm standard deviation $(\mathrm{n}=4) .5$-FU half inhibitory concentration, $200 \mathrm{mmol} / \mathrm{l} 48 \mathrm{~h}$ following treatment. 5-FU, 5-fluorouracil; OD, optical density at $490 \mathrm{~nm}$.

Table II. Effect of treatment time and celecoxib concentration on proliferation of SGC7901 cells under hypoxic conditions.

\begin{tabular}{|c|c|c|c|c|c|c|}
\hline \multirow[b]{2}{*}{ Group } & \multicolumn{2}{|r|}{$24 \mathrm{~h}$} & \multicolumn{2}{|r|}{$48 \mathrm{~h}$} & \multicolumn{2}{|c|}{$72 \mathrm{~h}$} \\
\hline & OD & Inhibition rate $(\%)$ & OD & Inhibition rate $(\%)$ & OD & Inhibition rate $(\%)$ \\
\hline Hypoxia & $0.520 \pm 0.020$ & & $0.678 \pm 0.023$ & & $0.840 \pm 0.022$ & \\
\hline Celecoxib & & & & & & \\
\hline $50 \mu \mathrm{mol} / 1$ & $0.476 \pm 0.018$ & 8.46 & $0.534 \pm 0.019$ & 21.24 & $0.737 \pm 0.019$ & 12.26 \\
\hline $100 \mu \mathrm{mol} / \mathrm{l}$ & $0.295 \pm 0.020$ & 43.27 & $0.348 \pm 0.016$ & 48.67 & $0.466 \pm 0.018$ & 44.52 \\
\hline $200 \mu \mathrm{mol} / 1$ & $0.244 \pm 0.017$ & 53.08 & $0.284 \pm 0.017$ & 58.11 & $0.385 \pm 0.014$ & 54.17 \\
\hline $300 \mu \mathrm{mol} / 1$ & $0.188 \pm 0.012$ & 60.50 & $0.207 \pm 0.013$ & 69.50 & $0.319 \pm 0.016$ & 62.02 \\
\hline
\end{tabular}

Mean \pm standard deviation $(\mathrm{n}=4)$. Celecoxib half inhibitory concentration, $100 \mu \mathrm{mol} / 148 \mathrm{~h}$ following treatment. OD, optical density at $490 \mathrm{~nm}$.

Table III. Inhibition ratio using half inhibitory concentrations of each drug alone or in combination.

\begin{tabular}{|c|c|c|c|c|c|c|}
\hline \multirow[b]{2}{*}{ Group } & \multicolumn{2}{|r|}{$24 \mathrm{~h}$} & \multicolumn{2}{|r|}{$48 \mathrm{~h}$} & \multicolumn{2}{|r|}{$72 \mathrm{~h}$} \\
\hline & OD & Inhibition rate $(\%)$ & OD & Inhibition rate $(\%)$ & OD & Inhibition rate $(\%)$ \\
\hline Hypoxia & $0.506 \pm 0.023$ & & $0.690 \pm 0.022$ & & $0.888 \pm 0.024$ & \\
\hline $5-\mathrm{FU}$ & $0.272 \pm 0.018$ & 46.25 & $0.358 \pm 0.019$ & 52.61 & $0.467 \pm 0.022$ & 47.41 \\
\hline Celecoxib & $0.306 \pm 0.027$ & 39.53 & $0.367 \pm 0.019$ & 46.81 & $0.504 \pm 0.021$ & 43.24 \\
\hline Combination & $0.210 \pm 0.011$ & 58.50 & $0.234 \pm 0.015$ & 66.09 & $0.390 \pm 0.014$ & 56.08 \\
\hline
\end{tabular}

Mean \pm standard deviation $(\mathrm{n}=4)$. 5-FU, 5-fluorouracil; OD, optical density at $490 \mathrm{~nm}$.

Western blot analysis. Cells were grouped and treated as described above. Cells were washed twice with chilled PBS following $24 \mathrm{~h}$ in culture. Radio-immunoprecipitation assay cell lysis solution (Biyuntian Biotech, Co.) was added, then kept in an ice bath for $30 \mathrm{~min}$. Cells were centrifuged $(100 \mathrm{x} \mathrm{g})$ for $10 \mathrm{~min}$ at $4^{\circ} \mathrm{C}$. The supernatant was collected and stored at $-70^{\circ} \mathrm{C}$. Proteins $(25 \mu \mathrm{g})$ were separated using SDS-PAGE, transferred to nitrocellulose membranes, and incubated for $2 \mathrm{~h}$ with $5 \%$ skimmed milk powder at $37^{\circ} \mathrm{C}$. Primary rabbit anti-HIF-2 $\alpha$, Oct-4 and ABCG2 polyclonal antibodies (dilution 1:50) and GAPDH were added and incubated overnight at $4^{\circ} \mathrm{C}$. Secondary horseradish peroxidase-labeled antibodies were added and incubated for $2 \mathrm{~h}$ at $37^{\circ} \mathrm{C}$. The antibodies were purchased from Abcam (Cambridge, MA, USA). Blots were quantified using an ECL reagent. The ratio of the absorbance value of HIF-2 $\alpha$, ABCG 2 and Oct- 4 was determined relative to GAPDH using the digital photo gel imaging system (Image J).

Statistical analysis. SPSS 17.0 (IBM, Armonk, NY, USA) was used for data processing and analysis. Continuous data are presented as the means \pm standard deviation and analyzed using a one-way analysis of variance, followed by a Dunnett's post-hoc T3 test. $\mathrm{P}<0.05$ was considered to indicate a statistically significant difference between values. 


\section{Results}

5-FU and celecoxib, alone or in combination, inhibit the proliferation of hypoxic SGC7901 cells. The proliferation of hypoxic SGC7901 gastric cancer cells was significantly inhibited in a dose-dependent manner by 5-FU (Table I) and celecoxib (Table II), $(\mathrm{P}<0.05$ for comparisons of all concentrations for 5-FU as well as celecoxib). Cells were in the logarithmic growth phase within $48 \mathrm{~h}$ following inoculation. The $\mathrm{IC}_{50}$ of 5-FU was $200 \mathrm{mg} / \mathrm{l}$, while the $\mathrm{IC}_{50}$ of celecoxib was $100 \mu \mathrm{mol} / 1$. The respective $\mathrm{IC}_{50}$ of $5-\mathrm{FU}$ and celecoxib were used in combination for the treatment of the 5-FU/celecoxib combination group. The combination treatment inhibited cell proliferation to a greater extent at each time-point than each treatment alone (Table III).

5-FU-treated cells express the highest levels of HIF-2 $\alpha$, ABCG 2 and Oct-4. Following $48 \mathrm{~h}$ in culture, immunohistochemical analysis revealed that the expression of HIF-2 $\alpha$, ABCG 2 and Oct- 4 proteins were the highest in the 5-FU group, followed by the hypoxia control group. The celecoxib and 5-FU/celecoxib combination groups demonstrated the lowest expression of the proteins (Figs. 1-3).

HIF-2 $\alpha, A B C G 2$ and Oct-4 expression levels are significantly reduced by celecoxib and 5-FU/celecoxib combination treatments. RT-qPCR was used to observe changes in HIF-2 $\alpha$, ABCG2 and Oct-4 mRNA expression in each group following $48 \mathrm{~h}$ in culture. HIF- $2 \alpha$, ABCG 2 and Oct- 4 expression levels were the highest in the 5-FU group, followed by the hypoxia control group, and significantly lower in the 5-FU/celecoxib combination and celecoxib groups $(\mathrm{P}<0.01)$ (Figs. 4 and 5).

HIF-2 $\alpha, A B C G 2$ and Oct-4 levels by western blot. Western blot analysis was used to observe the changes in HIF-2 $\alpha$, ABCG2 and Oct-4 expression following $48 \mathrm{~h}$ in culture. HIF-2 $\alpha$, ABCG 2 and Oct- 4 expression were the highest in the 5-FU group, followed by the hypoxia control group, and significantly lower in the 5-FU/celecoxib combination and celecoxib groups $(\mathrm{P}<0.01)$ (Figs. 6 and 7).

\section{Discussion}

5-FU is one of the most commonly used chemotherapeutic drugs, which is also employed to test the tumor susceptibility of gastric cancer cells in vitro $(7,8)$. The mechanism of 5-FU proceeds through inducing apoptosis via blocking DNA synthesis, which is done by restricting the progression of cells in the $\mathrm{S}$ phase of the cell cycle (13). However, cells have been shown to develop resistance to 5-FU, particularly solid tumor cells under hypoxic conditions $(4,7,8)$. Therefore, determining novel strategies to overcome this resistance is of prime importance.

The present study demonstrated that celecoxib or 5-FU alone were able to inhibit gastric cancer cell growth. Of note, the combination of the two drugs had a synergistic effect, further inhibiting the growth of tumor cells. The results also revealed that the expression levels of HIF-2 $\alpha$, ABCG2 and Oct- 4 were involved in the growth suppression of these tumor cells.
Previous studies have reported that small amounts of cancer stem cells were present in tumor tissues; these cells had an unlimited self-renewal ability and unlimited differentiation potential. Cancer stem cells are increasingly thought to be the cause of metastases and tumor recurrence as well as drug and radiation resistance $(14,15)$. However, little is currently known about these cells and their phenotypic marker profile has not yet been defined; therefore, purification of cancer stem cells is difficult.

HIF was reported to be closely associated with a malignant phenotype, which was involved in tumor angiogenesis, invasion and metastasis as well as drug and radiation resistance (16). HIF-2 $\alpha$, in comparison to HIF-1 $\alpha$, was shown to be more closely associated with cancer stem cells and maintains the stem cell phenotype via the regulation of several associated pathways (17). ABCG2, a member of the superfamily of transport proteins, was reported to be involved in the excretion of numerous chemotherapeutic drugs from cells; therefore, high expression of ABCG2 may be a significant contributing factor in tumor multi-drug resistance (18). Studies have shown that $\mathrm{ABCG} 2$ expression was high in numerous cancer stem cells, and that ABCG2 was a direct target gene of HIF-2 $\alpha$. This therefore indicated that high expression of HIF-2 $\alpha$ and ABCG2 may lead to the multi-drug resistance observed in tumor stem cells and hypoxic cells (19). Oct-4, a member of the Pit-Oct-Unc (POU) family of transcription factors, acts as a marker of cancer stem cell pluripotency $(20,21)$. Covello et al (17) demonstrated that Oct-4 was also a direct target gene of HIF-2 $\alpha$. This therefore indicated that hypoxia may induce the retention of a stem cell phenotype in tumor cells through activation of the HIF- $2 \alpha /$ Oct-4 pathway.

Dallas et al (22) reported a high expression of the stem cell phenotype (CD133+/CD44+) in colon cancer cell lines (HT29/5-FUR) resistant to 5-FU, therefore suggesting that the cancer stem cells resistant to 5-FU may be the source of chemotherapy resistance. A previous study showed that expression levels of HIF-2 $\alpha$ and ABCG2 were increased when 5-FU was added to the SGC7901 gastric cancer cells under hypoxic conditions, therefore indicating that this resistance may be associated with the induction of the HIF-2 $\alpha / A B C G 2$ pathway and promote the maintenance of the stem cell phenotype (23).

Celecoxib is a selective COX-2 inhibitor which has anti-inflammatory and analgesic effects (24). It is primarily used for the treatment of acute or chronic osteoarthritis as well as rheumatoid arthritis; in addition, celecoxib has fewer gastrointestinal side effects than other NSAIDs (9). Celecoxib was also reported to have certain anti-tumor effects (10-12). Steinbach et al (25) showed that celecoxib significantly reduced the occurrence of polyps in patients with familial adenomatous polyposis. In addition, chronic NSAID therapy may be able to reduce the risk of colon cancer by $50 \%$, as well as the incidence of esophageal and gastric cancer (26). Studies on animals showed that celecoxib prevented and inhibited gastric cancer carcinogenesis $(27,28)$. The results of the present study demonstrated that celecoxib inhibited the proliferation of SGC7901 gastric cancer cells. The inhibition rate of the combined 5-FU/celecoxib group was significantly increased compared with that of the 5-FU group; these results were consistent with those of a previous 

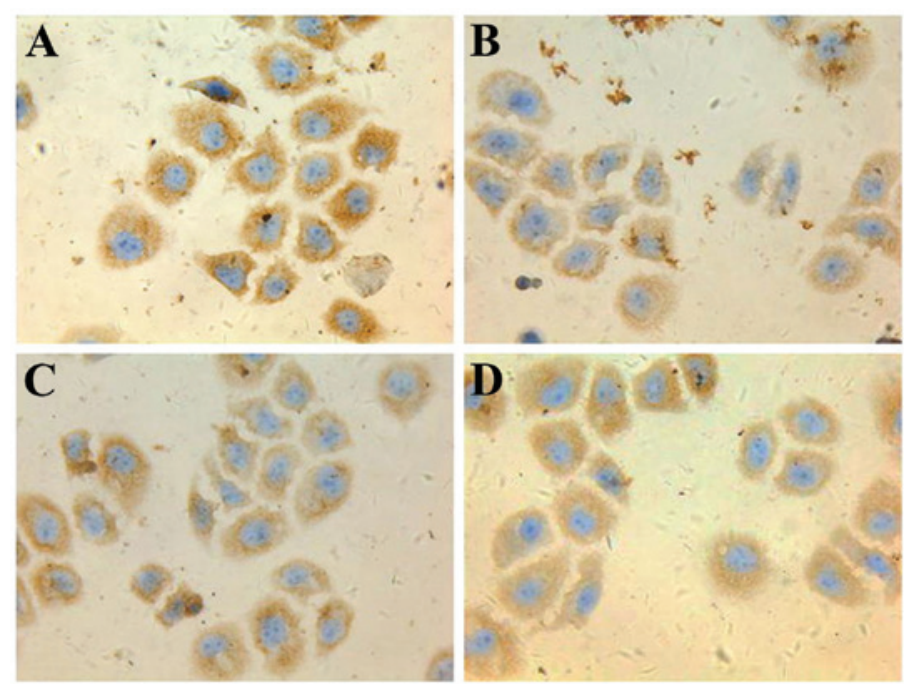

Figure 1. Hypoxia-inducible factor $2 \alpha$ expression in each group by immunocytochemistry (magnification, $\mathrm{x} 400$ ). (A) 5 -fluorouracil group; (B) celecoxib group; (C) combination group; and (D) hypoxia control group.
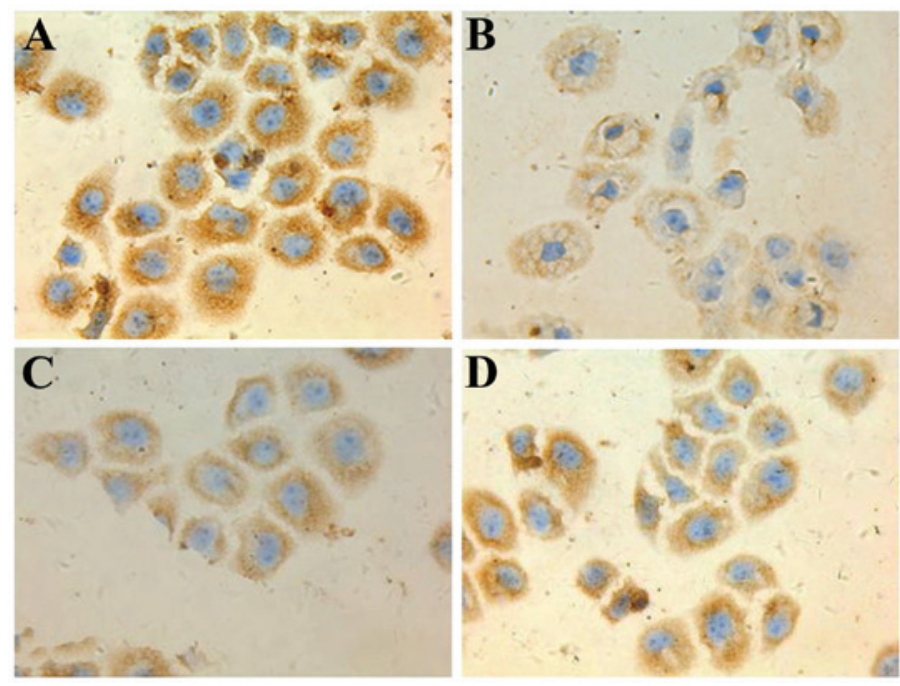

Figure 2. Adenosine triphosphate-binding cassette sub-family G member 2 expression in each group by immunocytochemistry (magnification, $\mathrm{x} 400$ ). (A) 5-fluorouracil group; (B) celecoxib group; (C) combination group; and (D) hypoxia control group.
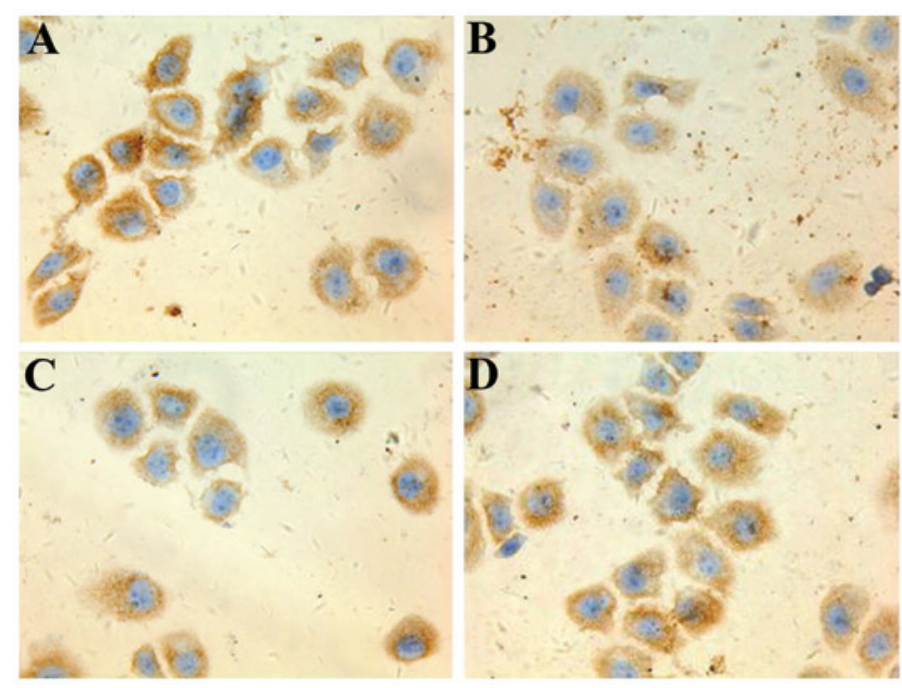

Figure 3. Octomer binding protein 4 expression in each group by immunocytochemistry (magnification, x400). (A) 5-fluorouracil group; (B) celecoxib group; (C) combination group; and (D) hypoxia control group. 


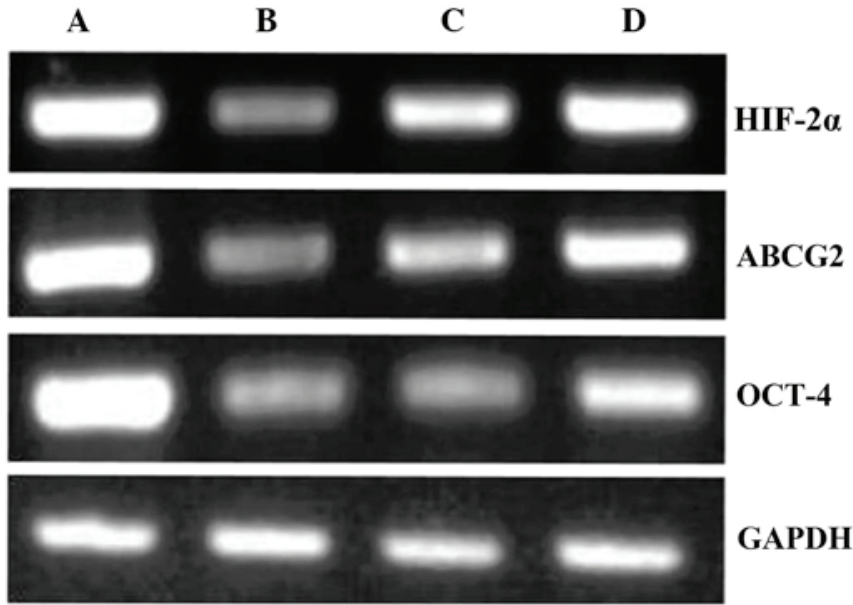

Figure 4. HIF-2 $\alpha$, ABCG2 and Oct-4 messenger RNA expression in each group using reverse transcription quantitative polymerase chain reaction. (A) 5-fluorouracil group; (B) celecoxib group; (C) combination group; and (D) hypoxia control group. HIF- $2 \alpha$, hypoxia-inducible factor $2 \alpha$ ABSG2, adenosine triphosphate-binding cassette sub-family G member 2; Oct- 4 , octamer binding protein 4 .

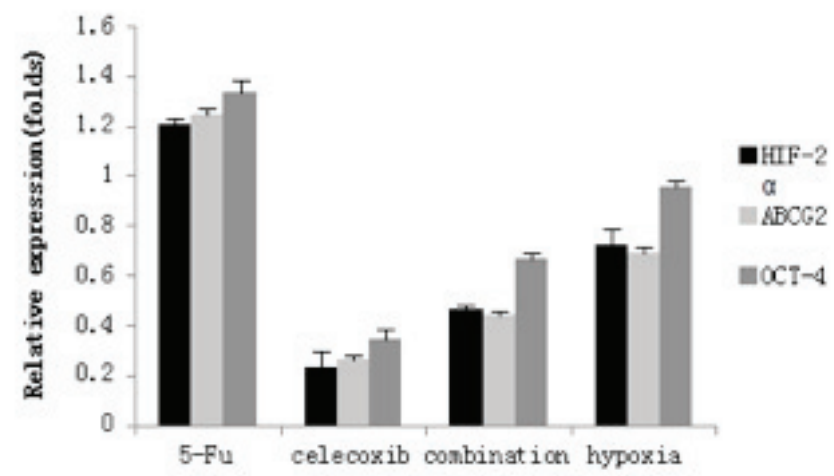

Figure 5. Quantification of HIF-2 $\alpha$, ABCG2 and Oct-4 mRNA expression in each group using reverse transcription quantitative polymerase chain reaction. Expression of HIF-2 $\alpha, \mathrm{ABCG} 2$ and Oct- 4 was different between all groups. HIF- $2 \alpha$, hypoxia-inducible factor $2 \alpha$; ABSG2, adenosine triphosphate-binding cassette sub-family G member 2; Oct-4, octamer binding protein 4.

study using rofecoxib combined with anti-tumor drugs on gastric cancer (29).

However, the mechanism of the anti-tumor effect of NSAIDs remains to be elucidated. Previous experiments have suggested that NSAIDs induce apoptosis of tumor cells through inhibiting COX-2 activity, therefore reducing the synthesis of prostaglandin E2 (30). However, Ding et al (31) observed that the mechanism of the anti-tumor effect of celecoxib occurs prior to the deterioration of oral mucosa cells. Numerous studies have suggested that celecoxib may promote tumor cell apoptosis via COX-2-independent pathways, and its effects on apoptosis may be achieved through the regulation of genes, including p21, Fas, protein kinase B, glycogen synthase kinase $3 \beta$, forkhead homolog in rhabdomyosarcoma, caspase-9, B cell lymphoma $2 / B$ cell
$\mathbf{A}$

B

C

D

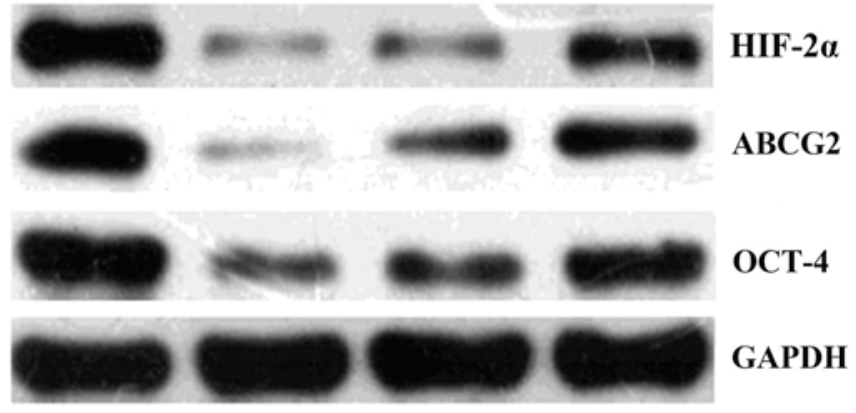

Figure 6. HIF-2 $\alpha, \mathrm{ABCG} 2$ and Oct-4 protein expression in each group using western blot analysis. (A) 5-fluorouracil group; (B) celecoxib group; (C) combination group; and (D) hypoxia control group. HIF-2 $\alpha$, hypoxia-inducible factor $2 \alpha$; ABSG2, adenosine triphosphate-binding cassette sub-family G member 2; Oct-4, octamer binding protein 4 .

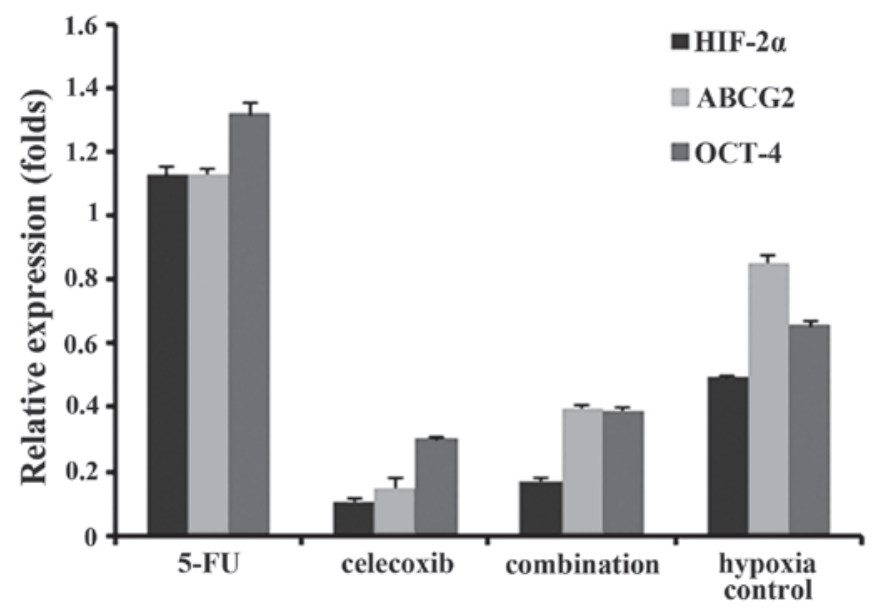

Figure 7. Quantification of HIF-2 $\alpha$, ABCG2 and Oct-4 protein expression in each group using western blot analysis. Expression of HIF-2 $\alpha$, ABCG2 and Oct- 4 was different between all groups. HIF- $2 \alpha$, hypoxia-inducible factor $2 \alpha$; ABSG2, adenosine triphosphate-binding cassette sub-family G member 2; Oct- 4 , octamer binding protein 4 .

lymphoma 2-associated X protein, p53 and survivin (32-35). However, further studies are required in order to elucidate the exact mechanisms underlying the effects of celecoxib in tumor cells.

In conclusion, the results of the present study demonstrated that celecoxib reduced $\mathrm{mRNA}$ and protein expression of HIF-2 $\alpha$, Oct-4 and ABCG2 in gastric cancer SGC7901 cells under hypoxic conditions. This therefore indicated that elevated expression of HIF-2 $\alpha$, ABCG2 and Oct- 4 mRNA may lead to 5-FU resistance. Furthermore, the results showed that celecoxib increased the efficacy of 5-FU in gastric cancer by reducing 5-FU resistance, therefore indicating its potential synergic use in chemotherapy treatment. However, clinical trials are required to confirm this hypothesis.

\section{Acknowledgements}

This study was supported by the Science and Technology Innovation Foundation of Affiliated Hospital of Weifang Medical University, and by a grant from the Shandong Province Science and Technology Program (no. 2012YD18108). 


\section{References}

1. Siegel R, Naishadham D and Jemal A: Cancer statistics, 2013. CA Cancer J Clin 63: 11-30, 2013.

2. Agboola O: Adjuvant treatment in gastric cancer. Cancer Treat Rev 20: 217-240, 1994.

3. Cunningham D, Allum WH, Stenning SP, et al: Perioperative chemotherapy versus surgery alone for resectable gastroesophageal cancer. N Engl J Med 355: 11-20, 2006.

4. Cosse JP and Michiels C: Tumour hypoxia affects the responsiveness of cancer cells to chemotherapy and promotes cancer progression. Anticancer Agents Med Chem 8: 790-797, 2008

5. Longley DB, Harkin DP and Johnston PG: 5-fluorouracil: mechanisms of action and clinical strategies. Nat Rev Cancer 3 : $330-338,2003$

6. Griffiths EA, Pritchard SA, Welch IM, Price PM and West CM Is the hypoxia-inducible factor pathway important in gastric cancer? Eur J Cancer 41: 2792-2805, 2005.

7. Liu L, Ning X, Sun L, et al: Hypoxia-inducible factor-1 alpha contributes to hypoxia-induced chemoresistance in gastric cancer. Cancer Sci 99: 121-128, 2008

8. Kang HC, Kim IJ, Park JH, Shin Y, Ku JL, Jung MS, Yoo BC Kim HK and Park JG: Identification of genes with differential expression in acquired drug-resistant gastric cancer cells using high-density oligonucleotide microarrays. Clin Cancer Res 10 : (1 Pt 1) 272-284, 2004.

9. Mathew ST, Devi SG, Prasanth VV and Vinod B: Efficacy and safety of COX-2 inhibitors in the clinical management of arthritis: Mini review. ISRN Pharmacol 2011: 480291, 2011.

10. Dannenberg AJ and Subbaramaiah K: Targeting cyclooxygenase-2 in human neoplasia: rationale and promise. Cancer Cell 4: 431-436, 2003.

11. Schönthal AH: Direct non-cyclooxygenase-2 targets of celecoxib and their potential relevance for cancer therapy. Br J Cancer 97: $1465-1468,2007$

12. Chuang HC, Kardosh A, Gaffney KJ, Petasis NA and Schönthal AH: COX-2 inhibition is neither necessary nor sufficient for celecoxib to suppress tumor cell proliferation and focus formation in vitro. Mol Cancer 7: 38, 2008

13. Yoshida K, Yamaguchi K, Osada S, Kawaguchi Y, Takahashi T, Sakashita F and Tanaka Y: Challenge for a better combination with basic evidence. Int J Clin Oncol 13: 212-219, 2008

14. Reya T, Morrison SJ, Clarke MF and Weissman IL: Stem cells, cancer, and cancer stem cells. Nature 414: 105-111, 2001.

15. Jordan CT, Guzman ML and Noble M: Cancer stem cells. N Engl J Med 355: 1253-1261, 2006

16. Mayer A and Vaupel P: Hypoxia, lactate accumulation, and acidosis: siblings or accomplices driving tumor progression and resistance to therapy? Adv Exp Med Biol 789: 203-209, 2013.

17. Covello KL, Kehler J, Yu H, Gordan JD, Arsham AM, Hu CJ, Labosky PA, Simon MC and Keith B: HIF-2alpha regulates Oct-4: effects of hypoxia on stem cell function, embryonic development, and tumor growth. Genes Dev 20: 557-570, 2006.

18. Hu L, McArthur C and Jaffe RB: Ovarian cancer stem-like side-population cells are tumourigenic and chemoresistant. Br J Cancer 102: 1276-1283, 2010.

19. Martin CM, Ferdous A, Gallardo T, Humphries C, Sadek H, Caprioli A, Garcia JA, Szweda LI, Garry MG and Garry DJ: Hypoxia-inducible factor-2alpha transactivates Abcg2 and promotes cytoprotection in cardiac side population cells. Circ Res 102: 1075-1081, 2008.
20. Nichols J,Zevnik B, Anastassiadis K, Niwa H, Klewe-Nebenius D, Chambers I, Schöler H and Smith A: Formation of pluripotent stem cells in the mammalian embryo depends on the POU transcription factor Oct4. Cell 95: 379-391, 1998.

21. Tai MH, Chang CC, Kiupel M, Webster JD, Olson LK and Trosko JE: Oct4 expression in adult human stem cells: evidence in support of the stem cell theory of carcinogenesis. Carcinogenesis 26: 495-502, 2005.

22. Dallas NA, Xia L, Fan F, et al: Chemoresistant colorectal cancer cells, the cancer stem cell phenotype, and increased sensitivity to insulin-like growth factor-I receptor inhibition. Cancer Res 69: 1951-1957, 2009.

23. Zhang XQ, Feng YG, Wu MY, Bai HX and Wang XY:The effect of 5-Fu on the ratio of SP cells and the expression of HIF-2a and ABCG2 in gastric cancer SGC7901 cell line under hypoxia. World Chinese Journal of Digestology 20: 1813-1818, 2012.

24. Rosas C, Sinning M, Ferreira A, Fuenzalida M and Lemus D: Celecoxib decreases growth and angiogenesis and promotes apoptosis in a tumor cell line resistant to chemotherapy. Biol Res 47: 27, 2014

25. Steinbach G, Lynch PM, Phillips RK, et al: The effect of celecoxib, a cyclooxygenase- 2 inhibitor, in familial adenomatous polyposis. N Engl J Med 342: 1946-1952. 2000.

26. Li M, Lotan R, Levin B, Tahara E, Lippman SM and Xu XC: Aspirin induction of apoptosis in esophageal cancer: a potential for chemoprevention. Cancer Epidemiol Biomarkers Prev 9: $545-549,2000$

27. Kuo CH, Hu HM, Tsai PY, et al: Short-term celecoxib intervention is a safe and effective chemopreventive for gastric carcinogenesis based on a Mongolian gerbil model. World J Gastroenterol 15: 4907-4914, 2009.

28. Rocha FT, Lourenço LG, Jucá MJ, Costa V and Leal AT: Chemoprevention by celecoxib in reflux-induced gastric adenocarcinoma in Wistar rats that underwent gastrojejunostomy. Acta Cir Bras 24: 189-194, 2009.

29. Tang C, Liu C, Zhou X and Wang C: Enhanced inhibitive effects of combination of rofecoxib and octreotide on the growth of human gastric cancer. Int J Cancer 112: 470-474, 2004.

30. Dandekar DS, Lopez M, Carey RI and Lokeshwar BL: Cyclooxygenase-2 inhibitor celecoxib augments chemotherapeutic drug-induced apoptosis by enhancing activation of caspase-3 and -9 in prostate cancer cells. Int J Cancer 115: 484-492, 2005.

31. Ding H, Han C, Zhu J, Chen CS and D'Ambrosio SM: Celecoxib derivatives induce apoptosis via the disruption of mitochondrial membrane potential and activation of caspase 9. Int J Cancer 113 803-810, 2005.

32. $\mathrm{Kim} \mathrm{N}, \mathrm{Kim} \mathrm{CH}$, Ahn DW, et al: Anti-gastric cancer effects of celecoxib, a selective COX-2 inhibitor, through inhibition of Akt signaling. J Gastroenterol Hepatol 24: 480-487, 2009.

33. Swamy MV, Herzog CR and Rao CV: Inhibition of COX-2 in colon cancer cell lines by celecoxib increases the nuclear localization of active p53. Cancer Res 63: 5239-5242, 2003.

34. Erkinheimo TL, Lassus H, Finne P, van Rees BP, Leminen A, Ylikorkala O, Haglund C, Butzow R and Ristimäki A: Elevated cyclooxygenase-2 expression is associated with alteredexpression of p53 and SMAD4, amplification of HER-2/neu, and poor outcome in serous ovarian carcinoma. Clin Cancer Res 10: $538-545,2004$.

35. Krysan K, Merchant FH, Zhu L, et al: COX-2-dependent stabilization of survivin in non-small cell lung cancer. FASEB J 18: 206-208, 2004 